\title{
CITRA PERUSAHAAN DALAM BERITA KRISIS PERUSAHAAN
}

\author{
Konstruksi Citra Perusahaan Daerah Taman Satwa (PDTS) Kebun Binatang Surabaya
} dalam Teks Berita Kematian Michael di Harian Jawa Pos dan Sindo

\author{
Theresia Intan Putri Hartiana \\ Fakultas Ilmu Komunikasi, Universitas Katolik Widya Mandala Surabaya
}

\begin{abstract}
ABSTRAK
Penelitian ini dilakukan untuk melihat bagaimana Harian Jawa Pos dan Sindo membentuk citra Perusahaan Daerah Taman Satwa (PDTS) Kebun Binatang Surabaya (KBS) dikonstruksikan dalam berita krisis kematian Michael. Metode yang digunakan dalam penelitian ini adalah framing Entman dengan merujuk pada pemberian definisi, penjelasan, evaluasi, dan rekomendasi wacana untuk melihat penekanan pada kerangka berpikir terhadap peristiwa yang dicanangkan. Citra PDTS KBS dalam Harian Jawa Pos memperlihatkan adanya kondisi Kebun Binatang Surabaya sudah tidak layak bagi satwanya dan kesengajaan keterlibatan orang dalam menjadi penyebab kematian Singa KBS mati tergantung. Citra PDTS KBS oleh Koran Sindo ditampilkan sebagai pihak yang harus bertanggungjawab atas kelalaian dan kecerobohannya dalam memelihara satwa sehingga mengakibatkan terjadi kematian satwa yang tidak wajar. Hal tersebut terlihat dari analisis makrostruktur teks yang memaparkan bahwa kepolisian dilibatkan untuk menyelidiki singa yang mati tergantung akibat kelalaian PDTS KBS dalam pengelolaan satwa. Pemberitaan yang dimunculkan oleh media massa patut menjadi perhatian oleh praktisi Public Relations. Berita yang dikonstruksi negatif secara terus menerus dapat memberikan pengaruh negatif pula di dalam benak pembaca. Beberapa pernyataan negatif yang muncul dalam teks pemberitaan dapat dijadikan sebagai dasar perencanaan bagi humas PDTS KBS dalam penanganan krisis dan perbaikan citra setelah krisis.
\end{abstract}

Kata-kata Kunci: Citra perusahaan, framing Entman, berita krisis, public relations

\section{CORPORATE IMAGES CONSTRUCTION IN CORPORATE CRISIS NEWS}

Construction of Surabaya Zoo (Perusahaan Daerah Taman Satwa Kebun Binatang Surabaya, PDTS KBS) company image in the news of Michael's death in the Jawa Pos and Sindo Daily News

\begin{abstract}
This research is done to discover How Jawa Pos and Koran Sindo constructing the image in the news of Surabaya Zoo (Perusahaan Daerah Taman Satwa Kebun Binatang Surabaya, PDTS KBS) on Michael's death crisis. The method used in this research is Entman framing, with reference to definitions, explanations, evaluations, and recommendations of the discourse, to see an emphasis on the framework of the event. Image of KBS in Jawa Pos Daily shows that Surabaya Zoo condition is inadequate for its animal and deliberate involvement from within the management is the cause of KBS lion hanged to its death. PDTS KBS image by Koran Sindo shows that PDTS KBS should responsible for negligence and carelessness in maintaining the animals welfare resulting in animals unnatural death. It can be seen from the analysis of the macrostructure text, which explains that the police involved in the investigation of KBS lion hanged to its death due to its negligence in managing the animals. The news occur in mass media should become a concern to Public Relations practitioners. A continuously constructed negative news could have a negative effect in the mind of the reader. Some negative statements that appear in the text of the news can be used as a basis for PDTS $K B S$ 's public relations planning to manage crisis and to improve image of the company after the crisis.
\end{abstract}

Keywords: Company image, Entman framing, crisis news, public relations

Korespondensi: Theresia Intan Putri Hartiana, S.Sos. Fakultas Ilmu Komunikasi, Universitas Katolik Widya Mandala Surabaya, Jl. Dinoyo 48A, Surabaya, Jawa Timur, 60265.Email: theresiaintan2502@gmail.com 


\section{PENDAHULUAN}

Kehadiran media pada saat terjadi krisis dapat memberikan beberapa manfaat bagi Public Relations. Media menjadi mitra yang menguntungkan dalam tiga hal: (1) untuk menyebarkan informasi tentang situasi terkini krisis secara luas dan berulang-ulang. Informasi ini untuk menjelaskan langkahlangkah yang sudah, sedang dan apa yang akan dilakukan perusahaan sehingga publik merasakan kecukuan informasi. (2) sarana memperoleh umpan balik dari publik. Publik dapat mengungkapkan opininya lewat surat pembaca (3) sebagai sarana memonitor tentang kondisi organisasi, isu-isu, produk, pesaing, kecenderungan-kecenderungan (trend) maupun lingkungan sosial secara keseluruhan yang tercermin dari berita-berita media (Kriyantono, 2012: 202).

Memonitor kecenderungan berita, seorang Public Relations haruslah memahami bahwa pemberitaan media adalah usaha konstruksi realitas. Terlebih dalam pemberitaan krisis perusahaan (Regester, Michael \& Judy Larkin, 2008: 19) tak jarang media menuliskan hal buruk mengenai perusahaan. Media lebih berusaha mengambil simpati pembaca dengan lebih menitikberatkan pada korban dan mempercayai bahwa perusahaan merupakan sumber utama krisis terjadi. (Regester, Michael \& Judy Larkin, 2008: 192).

Hal inilah yang patut diperhatikan karena dalam sebuah berita akan mampu mengarahkan pada citra perusahaan. Seperti halnya yang terlihat dalam pemberitaan kematian satwa yang dialami oleh Perusahaan Daerah Taman Satwa (PDTS) Kebun Binatang Surabaya. Kematian Michael, Singa Afrika koleksi Kebun Binatang Surabaya pada 7 Januari 2014 memunculkan banyak perhatian, karena cara kematiannya yang dianggap tidak wajar. Michael mati dengan jeratan tali sling di leher dan posisi tergantung layaknya bunuh diri. Harian Jawa Pos dan Koran Sindo, sebagai media massa cetak populer di Surabaya, turut menuliskan pemberitaan kematian Michael dan menempatkannya di halaman nasional surat kabarnya pada keesokan harinya di tanggal 8 Januari 2014. Dalam konteks Public Relations berita terkait kematian Michael merupakan krisis bagi sebuah perusahaan .

Munculnya krisis akibat kejadian matinya
Michael, Singa Jantan Kebun Binatang Surabaya, tentulah tidak luput dari pemberitaan media. Terlebih dalam pemberitaan krisis perusahaan, tak jarang media menuliskan hal buruk mengenai perusahaan. Media lebih berusaha mengambil simpati pembaca dengan lebih menitikberatkan pada korban dan mempercayai bahwa perusahaan merupakan sumber utama krisis terjadi. (Regester, Michael \& Judy Larkin.2008:192)

Melalui beberapa strategi yang biasa dilakukan dalam membuat wacana, yaitu pemilihan simbol (fungsi bahasa), pemilihan fakta yang akan disajikan (strategi framing), kesedian memberi tempat (agenda setting). (Hamad, 2004:24) teks pemberitaan akan kematian satwa di Harian Jawa Pos dan Koran Sindo mampu menyebabkan berbagai dampak bagi Perusahaan Daerah Taman Satwa (PDTS) Kebun Binatang Surabaya, seperti buruknya citra PDTS KBS tersebut.

Harian Jawa Pos dan Koran Sindo, sebagai media massa cetak populer di Surabaya, turut menuliskan pemberitaan kematian Michael dan menempatkannya di halaman nasional surat kabarnya pada keesokan harinya di tanggal 8 Januari 2014. Melalui pemberitaan yang dituliskan itulah peneliti mengamati, wacana mengenai buruknya citra Perusahaan Daerah Taman Satwa (PDTS) Kebun Binatang Surabaya dimunculkan melalui beberapa pernyataan dan gambar di Harian Jawa Pos dan Koran Sindo.

Jawa Pos, pada terbitan tanggal 8 Januari 2014 menuliskan "Kuburan Satwa Surabaya" sebagai julukan baru yang diberikan Jawa Pos dalam judul gambar daftar satwa mati yang terjadi di Kebun Binatang Surabaya sejak setahun terakhir.

Selain itu Jawa Pos juga berhasil memunculkan foto kematian Michael yang yang tergantung di tali sling baja. Penggambaran kondisi yang mengenaskan Kebun Binatang Surabaya bagi hewannya, tergambar pula dalam paragaraf peratama Jawa Pos:

"Kondisi Kebun Binatang Surabaya (KBS) semakin memprihatinkan. Kematian satwa terus terjadi di tempat penampungan hewan di tengah Kota Surabaya itu. Begitu parahnya kondisi KBS, seekor raja hutan pun yang begitu ditakuti di habitatnya mati dalam kondisi mengenaskan" (Jawa Pos, 8 Januari 2014) 


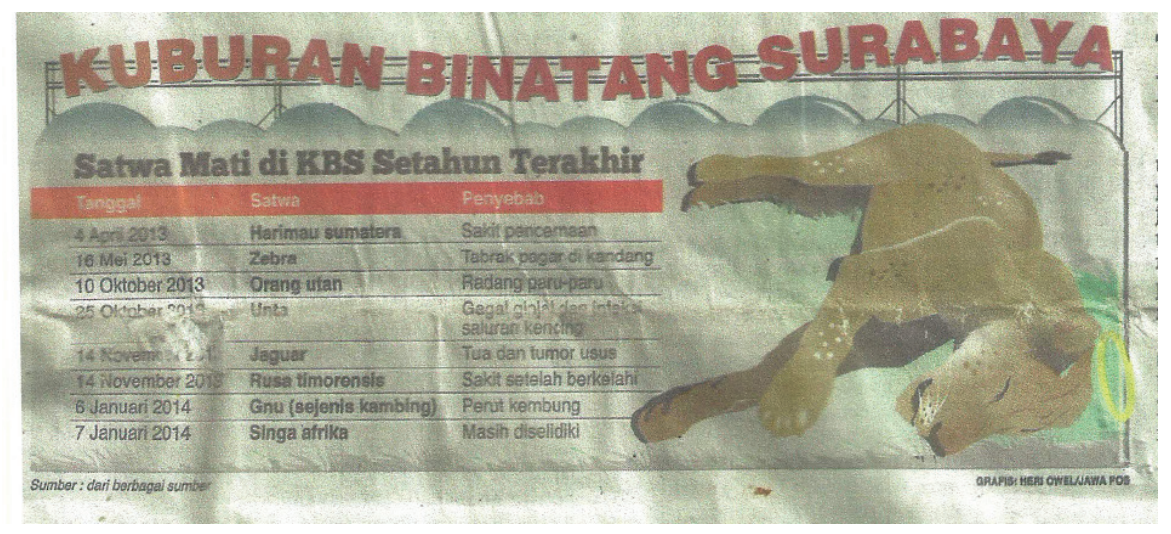

Gambar 1 Kuburan Binatang Surabaya, akronim baru untuk KBS (Kebun Binatang Surabaya) yang dituliskan Jawa Pos 8 Januari 2014

Jawa Pos juga meyakinan wacana yang dikembangkan dalam paragraf dengan menuliskan kematian beruntun yang terjadi sehari sebelum kematian Michael terjadi.

"Selang satu hari setelah seekor gnu (sebangsa rusa) mati gara - gara kembung, KBS kembali kehilangan satwa Kemarin (7/1) seekor singa afrika bernama Michael tewas di kandangnya. Anehya, kematian raja hutan tersebut tidak lazim, kondisi Michael tergantung. Lehernya terlilit tali baja atau sling pembuka pintu" (Koran Sindo, 8 Januari 2014)

Begitupula Koran Sindo menuliskan "Menunggu kematian di KBS" sebagai judul foto beritanya. Peneliti mengintepretasikan, judul yang diberikan dapat menciptakan persepsi negatif dalam benak pembaca bahwa Kebun Binatang Surabaya, menjadi tempat kematian bagi satwa - satwa didalamnya. Terlebih lagi, dalam Koran Sindo terbitan 8 Januari tersebut, memberikan gambar daftar kematian satwa yang pernah terjadi di Kebun Binatang Surabaya sejak tahun 2010 hingga tahun 2014.

Penyataan dalam caption gambar Koran Sindo diatas, juga menampilkan penyataan negatif mengenai Perusahaan Daerah Taman Satwa (PDTS) Kebun Binatang Surabaya.

"Kasus satwa tewas yang diduga disebabkan buruknya manajemen Kebun Binatang Surabaya (KBS) kembali terjadi. Di awal 2014, sudah ada dua koleksi KBS yang tewas tak wajar. Keduanya menambah

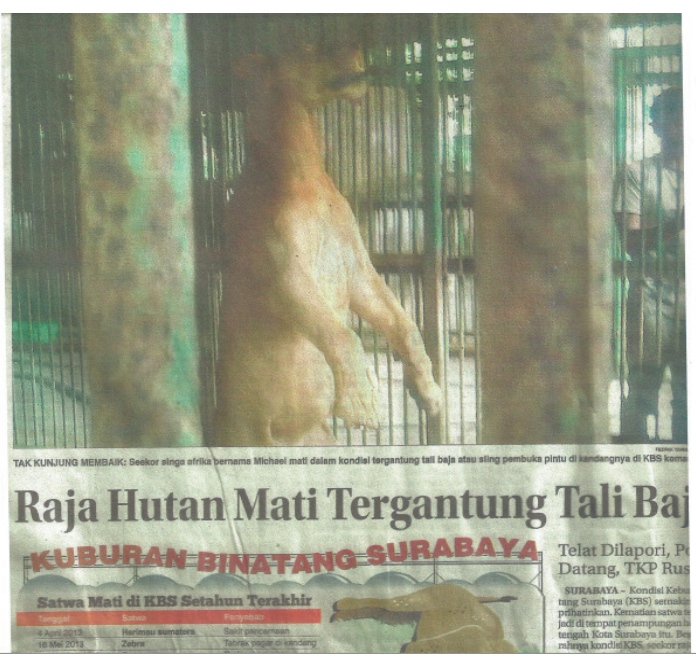

Gambar 2 Foto Michael, Singa Afrika yang Mati Tergantung Tali Sling yang Mati Tergantung Tali Sling di halaman Berita Jawa Pos, 8 Januari 2014 


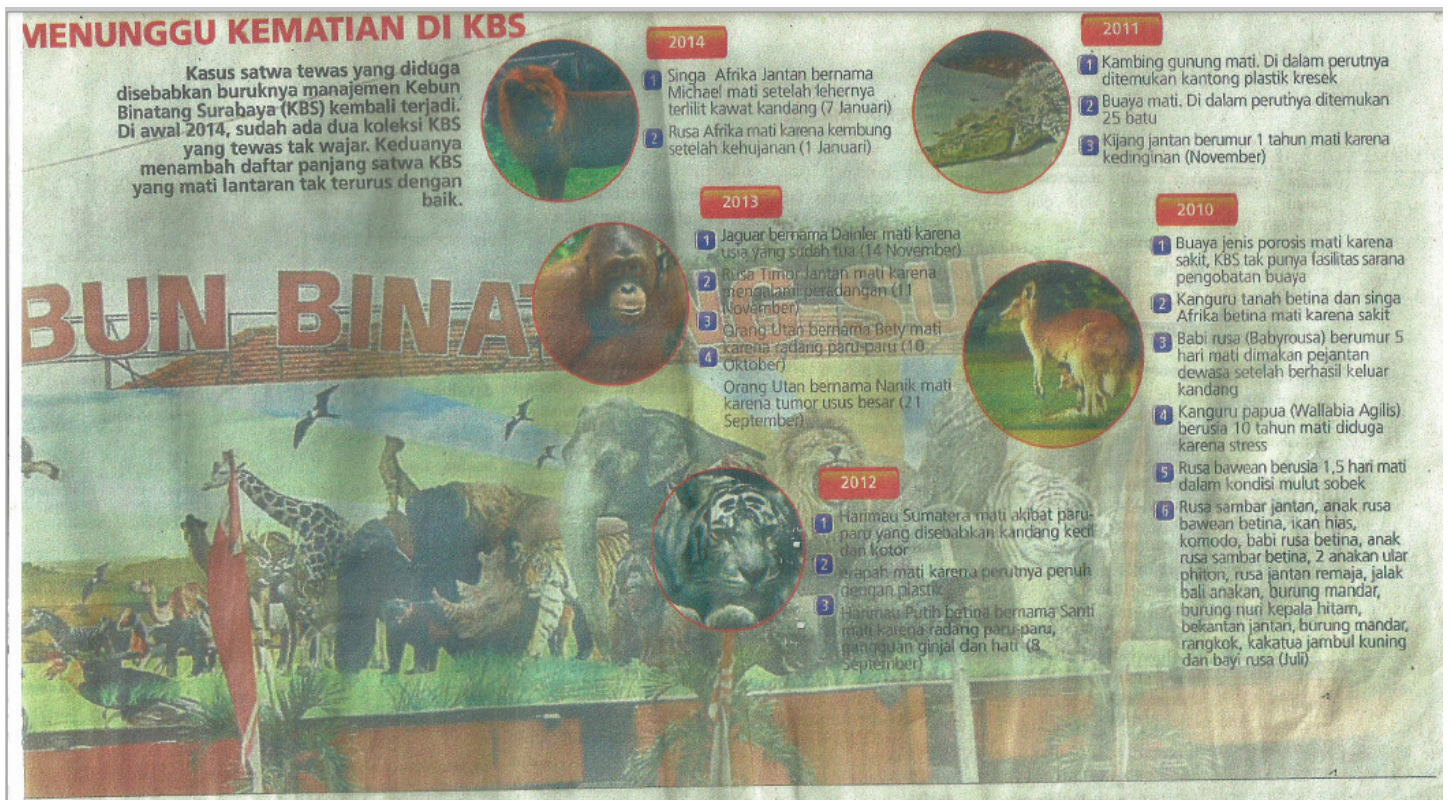

\section{Gambar 3 Ilustrasi Gambar Daftar Kematian Satwa di Kebun Binatang sejak tahun 2010 oleh Koran Sindo pada 8 Januari 2014}

daftar panjang satwa KBS yang mati lantaran tak terurus dengan baik" (Jawa Pos, 8 Januari 2014)

Hal tersebut semakin diperburuk dengan paragraf pertama dalam cutline yang dituliskannya, dimana dalam paragraph tersebut menjadikan Perusahaan Daerah Taman Satwa (PDTS) Kebun Binatang Surabaya seolah - olah diposisikan sebagai pembunuh dan penyebab utama kematian satwa.

"Pergantian pengelola Kebun Binatang Surabaya (KBS) ternyata juga tidak membawa nasib baik bagi para satwa penghuninya. Kematian yang disebabkan kecerobohan atau kelalaian pengelola tetap menghantui ratusan satwa tak berdosa tersebut. Dalam dua hari berturut-turut, dua satwa koleksi KBS Mati” (Koran Sindo, 8 Januari 2014)

Dalam pengambilan kutipan narasumber berita, Koran Sindo juga menampilkan Michale Sumampau, Ketua Forum Konservasi Satwa Liar Indonesia (FOKSI) Jawa Timur sebagai pendukung wacana akan kelalaian Perusahaan Daerah Taman Satwa (PDTS) Kebun Binatang Surabaya yang diletakkannya di awal paragrafnya.

\begin{abstract}
"Michale juga menduga kematian satwasatwa KBS disebabkan perawatan kandangnya yang buruk. Hal ini diperarah dengan tidak berimbangnya jumlah satwa dengan kandang yang tersedia“. (Koran Sindo, 8 Januari 2014)
\end{abstract}

Jean Baudrillard (1981) mengungkapkan antara realitas yang ditampilkan akan mampu mengarahkan pada relasi citra. Pertama, citra dikatakan merupakan refleksi dari realitas. Kedua, citra menopengi dan memutarbalikkan realitas. Ketiga, Citra menopengi ketiadaan realitas Keempat, citra tidak berkaitan dengan realitas apapun. (Piliang, 2003: 46)

Suatu peristiwa,termasuk dalam berita krisis Public Relations memiliki 3 kategori realitas, yakni: Pertama realitas obyektif, yaitu realitas yang ditampilkan sesuai dengan apa yang sebenarnya terjadi. Kedua realitas subyektif, yaitu realitas yang dipersepsikan oleh khalayak atau aktor itu sendiri. Ketiga realitas yang dikonstruksi, yaitu realitas yang juga subyektif tapi di-cover melalui media.

Dalam konteks ini, peneliti berpendapat bahwa bahasa yang dihadirkan dalam teks berita bukanlah sekedar wacana dan tidak cukup hanya didasarkan pada analisis atas teks semata. Disini juga harus dilihat juga bagaimana suatu teks diproduksi, yang didalamnya didalamnya sarat 
akan kepentingan, fakta, konflik yang beragam, sehingga memperoleh suatu pengetahuan kenapa Harian Jawa Pos dan Koran Sindo menghasilkan teks semacam itu,

Harian Jawa Pos dan Koran Sindo sebagai suatu alat untuk menyampaikan berita, penilaian atau gambaran umum tentang banyak hal, mempunyai kemampuan untuk berperan sebagai institusi yang dapat membentuk persepsi publik, antara lain karena media juga dapat berkembang menjadi kelompok penekan atas suatu ide atau gagasan, dan bahkan suatu kepentingan atau citra yang direpresentasikan untuk diletakkan dalam konteks kehidupan yang lebih empiris. Sehubungan dengan hal tersebut, sebenarnya media dapat memberi pengaruh positif maupun negatif melalui atribut normatif berdasarkan dimensi kepentingan yang diwakili. (Sobur.2002:35)

Harian Jawa Pos dan Koran Sindo dalam konteks pemberitaan kematian satwa ini juga bertindak sebagai penyampai realitas kepada masyarakat dengan melakukan konstruksi berita dengan pemilihan simbol, pemilihan fakta dan agenda setting yang dilakukan. Hal ini terlihat dari sudut pandang pemberitaan yang berbeda satu sama lain. Realitas sesungguhnya mengenai kematian satwa disusun kembali oleh wartawan menjadi realitas baru hingga membentuk wacan yang bermakna . Realitas yang dihadirkan Koran Sindo dan Harian Jawa Pos inilah yang mengarahkan pembaca kepada realitas citra Perusahaan Daerah Taman Satwa (PDTS) Kebun Binatang Surabaya.
Bagaimanakah konstruksi citra Perusahaan Daerah Taman Satwa (PDTS) Kebun Binatang Surabaya yang ditampilkan Jawa Pos dan Koran Sindo dalam berita kematian Michael?

\section{METODE PENELITIAN}

Frame media dengan demikian adalah bentuk yang muncul dari pikiran (kognisi), penafsiran, dan penyajian, dari seleksi, penekanan, dan pengucilan dengan menggunakan simbol-simbol yang dilakukan secara teratur dalam wacana yang terorganisir, baik dalam bentuk verbal maupun visual (Gitlin dalam Eriyanto, 2005: 69). Adapun Framing adalah sebuah strategi bagaimana realitas atau dunia dibentuk dan disederhanakan sedemikian rupa untuk ditampilkan kepada khalayak pembaca. Peristiwa-peristiwa ditampilkan dalam pemberitaan agar tampak menonjol dan menarik perhatian khalayak pembaca (Gitlin dalam Eriyanto, 2005: 68).

Dalam penelitian ini, peneliti menganalisis frame berdasarkan model Entman. Dalam konsepsi Entman (Eriyanto, 2005: 188), framing pada dasarnya merujuk pada pemberian definisi, penjelasan, evaluasi, dan rekomendasi dalam suatu wacana untuk menekankan kerangka berpikir terhadap peristiwa yang dicanangkan.

\section{HASIL DAN PEMBAHASAN}

Pemberitaan terkait Perusahaan Daerah

\section{Tabel 1 Framing Model Entman}

\begin{tabular}{|c|c|}
\hline $\begin{array}{l}\text { Define Problems } \\
\text { (Mendefinisikan masalah) }\end{array}$ & $\begin{array}{l}\text { Bagaimana suatu peristiwa atau isu } \\
\text { dilihat? Atau sebagai masalah apa? }\end{array}$ \\
\hline $\begin{array}{l}\text { Diagnoses Causes } \\
\text { (Memperkirakan masalah atau } \\
\text { sumber masalah) }\end{array}$ & $\begin{array}{l}\text { Peristiwa itu dilihat disebabkan oleh apa? } \\
\text { Apa yang dianggap sebagai penyebab } \\
\text { dalam suatu masalah? Siapa (aktor) yang } \\
\text { dianggap sebagai penyebab masalah? }\end{array}$ \\
\hline $\begin{array}{l}\text { Make moral judgement } \\
\text { (Membuat keputusan moral) }\end{array}$ & $\begin{array}{l}\text { Nilai moral apa yang disajikan untuk } \\
\text { menjelaskan masalah? Nilai moral apa } \\
\text { yang dipakai untuk melegitimasi atau } \\
\text { mendelegitimasi suatu tindakan? }\end{array}$ \\
\hline $\begin{array}{l}\text { Treatment Recommendation } \\
\text { (Menekankan penyelesaian) }\end{array}$ & $\begin{array}{l}\text { Persoalan apa yang ditawarkan untuk } \\
\text { mengatasi masalah atau isu? Jalan apa } \\
\text { yang ditawarkan dan harus ditempuh } \\
\text { untuk mengatasi masalah? }\end{array}$ \\
\hline
\end{tabular}


Tabel 2 Deskripsi ringkas Berita Penyebab Terjadinya Krisis oleh Jawa Pos

\begin{tabular}{|c|c|c|c|}
\hline Judul & Lead & Isi Berita & Sumber Berita \\
\hline $\begin{array}{l}\text { Raja Hutan Mati } \\
\text { Tergantung Tali Baja } \\
\text { dengan sub judul: } \\
\text { J1: Telat dilapori, Polisi } \\
\text { Datang, TKP Rusak } \\
\text { J2: Polisi Harus Ungkap } \\
\text { Keterlibatan Orang } \\
\text { Dalam }\end{array}$ & $\begin{array}{l}\text { Kondisi Kebun } \\
\text { Binatang Surabaya } \\
\text { (KBS) semakin } \\
\text { memprihatinkan. } \\
\text { Kematian satwa terus } \\
\text { terjadi di tempat } \\
\text { penampungan hewan di } \\
\text { tengah Kota Surabaya } \\
\text { itu. } \\
\text { Begitu parahnya kondisi } \\
\text { KBS, seekor raja hutan } \\
\text { pun yang begitu ditakuti } \\
\text { di habitatnya mati dalam } \\
\text { kondisi mengenaskan }\end{array}$ & $\begin{array}{l}\text { Kondisi KBS yang } \\
\text { memprihatinkan dengan } \\
\text { terus terjadinya kematian } \\
\text { satwa. } \\
\text { Terdapat Kematian } \\
\text { satwa KBS yang disertai } \\
\text { kejanggalan penyebab } \\
\text { kematiannya, yaitu } \\
\text { digantung. } \\
\text { Adanya unsur keterlibatan } \\
\text { pihak dalam Perusahaan } \\
\text { Daerah Taman Satwa } \\
\text { (PDTS) Kebun Binatang } \\
\text { Surabaya dalam kasus } \\
\text { kematian Michael, Singa } \\
\text { Afrika. } \\
\text { Terlambatnya waktu } \\
\text { pelaporan kejadian } \\
\text { Michael dan olah TKP } \\
\text { yang tidak maksimal } \\
\text { karena TKP sudah tidak } \\
\text { murni. }\end{array}$ & $\begin{array}{l}\text { Direktur } \\
\text { Operasional } \\
\text { Perusahaan Daerah } \\
\text { Taman Satwa } \\
\text { (PDTS) KBS } \\
\text { Sekkota Surabaya } \\
\text { Hendro Gunawan } \\
\text { Kasatreskrim } \\
\text { Polrestabes } \\
\text { Surabaya AKBP } \\
\text { Farman }\end{array}$ \\
\hline
\end{tabular}

Taman Satwa (PDTS) Kebun Binatang Surabaya memang tak pernah habis dibahas oleh media massa di Surabaya. Berbagai kejadian mulai dari kematian hewan dan pergantian pengelola masih menjadi topik hangat. Terlebih lagi di tanggal 7 Januari 2015 Perusahaan Daerah Taman Satwa (PDTS) Kebun Binatang Surabaya menjadi sorotan karena kasus kematian Michael, Singa Afrika yang mati secara tidak wajar dengan cara digantung.

Harian Jawa Pos dan Koran Sindo, sebagai media massa cetak populer di Surabaya, turut menuliskan pemberitaan kematian Michael dan menempatkannya di halaman nasional surat kabarnya pada keesokan harinya di tanggal 8 Januari 2014. Melalui pemberitaan yang dituliskan itulah peneliti mengamati wacana mengenai buruknya citra Perusahaan Daerah Taman Satwa (PDTS) Kebun Binatang Surabaya yang dimunculkan melalui beberapa pernyataan dan gambar di Harian Jawa Pos dan Koran Sindo.

Harian Jawa Pos dalam skema

pemberitaannya lebih menekankan pada adanya unsur kesengajaan dibalik kematian Michael, singa afrika koleksi Kebun Binatang Surabaya. Kesengajaan yang dimaksud dalam berita ini ada 2 pengertian: sengaja di bunuh dan sengaja dihilangkan jejak kematiannya oleh pihak Perusahaan Daerah Taman Satwa (PDTS) Kebun Binatang Surabaya sendiri.

Unsur kesengajaan inilah yang menjadi nilai penting dari latar peristiwa yang diberikan Harian Jawa Pos sebagai penjelas kondisi Kebun Binatang Surabaya. Penyataan tersebut didukung dengan penulisan beruntun bagaimana seekor binatang dapat menggantungkan tubuhnya padahal kondisi Michael yang sehari harinya sangat lincah, tidak pernah sakit dan nafsu makannya normal. Dari sisi kondisi kandang, Jawa Pos turut mendeskripsikan secara jelas bahwa tali sling yang terkait di leher Michael terbuat dari tali baja sehingga tidak elastis, dan tali sling tersimpul rapat di sebelah pintu. Penggunaan tali baja sebagai pembuka pintu juga sesuai standard internasional seperti 
Tabel 3 Deskripsi Ringkas Berita Penyebab Terjadinya Krisis oleh Koran Sindo

\begin{tabular}{|c|c|c|}
\hline Judul & Isi Berita & Sumber Berita \\
\hline $\begin{array}{l}\text { Polisi Didesak } \\
\text { Selidiki Satwa } \\
\text { Tewas }\end{array}$ & $\begin{array}{l}\text { Kematian satwa yang disebabkan } \\
\text { kecerobohan pengelola } \\
\text { Terdapat unsur kesengajaan dalam } \\
\text { kematian Michael } \\
\text { Pemerintah Kota Surabaya baru } \\
\text { mengambil tindakan setelah ada } \\
\text { kematian satwa berturut - turut } \\
\text { Polisi turut dilibatkan dalam kasus } \\
\text { Michael }\end{array}$ & $\begin{array}{l}\text { Ketua Komisi B, DPRD Kota } \\
\text { Surabaya, Rusli Yusuf } \\
\text { Ketua Forum Konservasi Satwa Liar } \\
\text { Indonesia (Foksi) Jatim, Michael } \\
\text { Sumampau } \\
\text { Humas PDTS KBS Agus Supangat } \\
\text { Sekretaris Kota (Sekkota) Surabaya } \\
\text { Hendro Gunawan } \\
\text { Direktur Operasional Perusahaan } \\
\text { Daerah Taman Satwa (PDTS) KBS, } \\
\text { Liang Kaspe } \\
\text { Kepala satuan (Kasat) Polisi Pamong } \\
\text { Praja (Pol PP) Kota Surabaya, Irvan } \\
\text { Widianto }\end{array}$ \\
\hline
\end{tabular}

di negara lain.

Dari waktu kematian yang terjadi di malam hari, Jawa Pos juga menuliskannya dengan diperkuat pernyataan drh.Liang Kaspe bahwa pada saat malam tidak ada pawang atau keeper kandang. Yang tersisa hanya petugas sekuriti. Sehingga dalam pemberitaannya Harian Jawa Pos menduga adanya unsur keterlibatan orang dalam Perusahaan Daerah Taman Satwa (PDTS) Kebun Binatang Surabaya. Kejanggalan yang lain tentang kematian Michael adalah waktu kematiannya. Diduga, hewan tersebut dibunuh saat malam (Jawa Pos, 2014).

Namun di sisi lain, unsur kejanggalan kedua juga mengarah pada pengertian sengaja dihilangkan jejak kematian oleh pihak Perusahaan Daerah Taman Satwa (PDTS) Kebun Binatang Surabaya. Hal tersebut nampak pada uraian rinci bagaimana keterlambatan pelaporan, kondisi kandang yang sudah bersih sebelum petugas datang yang dipertegas dengan penyataan dari Kasatreskrim Polrestabes Surabaya AKBP Farman yang mengatakan "Kasus kematian Singa baru dilaporkan pukul 15.30. Laporan itu langsung ditindaklanjuti dengan menerjunkan tim identifikasi dan olah TKP. Tapi kondisi TKP-nya sudah rusak (Jawa Pos, 2014).

Menurut Farman, ketika hendak meneliti lokasi TKP, petugas terperangah karena kondisi sudah kosong. Singa yang disebut tergantung sudah tidak ada di tempatnya. Menurut dia, TKP sudah tidak murni (Jawa Pos, 2014). Akibat rusaknya TKP, jelas Farman, sampai berita ini ditulis pihaknya belum mengetahui posisi binatang tersebut saat tergantung, TKP sudah rusak. Olah TKP jadi tidak maksimal, sesalnya (Jawa Pos, 2014). Paragraf juga ditutup dengan pertanyaan adakah unsur kesengajaan dalam pemindahan oleh Harian Jawa Pos ditulis dengan jawaban tidak langsung, bahwa polisi akan menelusurinya.

Selanjutnya pada diagnosis causes, Harian Koran Sindo menuliskan Lead -nya dengan pernyataan:

"Pergantian pengelola Kebun Binatang Surabaya (KBS) ternyata tak juga membawa nasib baik bagi para satwa penghuninya. Kematian yang disebabkan kecerobohan atau kelalaian pengelola tetap menghantui ratusan satwa tak berdosa tersebut. Dalam dua hari berturut turut, dua satwa koleksi KBS mati" (Sindo, 2014).

Koran Sindo, dalam lead tersebut langsung memberikan penekanan bahwa Perusahaan Daerah Taman Satwa (PDTS) Kebun Binatang Surabaya telah lalai dalam pengelolaan sehingga kematian satwa dalam 2 hari berturut turut adalah kesalahan pihak Perusahaan 
Tabel 4 Define Problems

\begin{tabular}{|c|l|}
\hline \multicolumn{1}{|c|}{ Jawa Pos } & \multicolumn{1}{c|}{ Koran Sindo } \\
\hline unsur kesengajaan dibalik kematian Michael & $\begin{array}{l}\text { kelalaian dan kecerobohan yang disebabkan } \\
\text { pihak pengelola }\end{array}$ \\
\hline
\end{tabular}

Daerah Taman Satwa (PDTS) Kebun Binatang Surabaya. Koran Sindo, secara tidak langsung melakukan generalisasi atas penyebab kematian satwa yang mati sebelumnya.

Kecerobohan, adalah tindakan akibat tidak berhati hati, tidak dipikirkan baik-baik (Kamus Besar Bahasa Indonesia, 2008). Kelalaian, merupakan tindakan kurang berhati hati, tidak mengindahkan kewajiban, pekerjaan (Kamus Besar Bahasa Indonesia, 2008). Kecerobohan dan kelalaian, kata sifat yang dilekatkan pada Perusahaan Daerah Taman Satwa (PDTS) Kebun Binatang Surabaya sebagai pengelola yang tidak bertanggungjawab dan tidak berhatihati dalam penanganan hewan.

Lead Jawa Pos lebih menekankan pada kondisi umum yang ada di Kebun Binatang Surabaya daripada sekedar mencari aktor utama dalam kasus kematian Michael: Kondisi Kebun Binatang Surabaya (KBS) semakin memprihatinkan. Kematian satwa terus terjadi di tempat penampungan hewan di tengah Kota Surabaya itu. Begitu parahnya kondisi KBS, seekor raja hutan pun yang begitu ditakuti di habitatnya mati dalam kondisi mengenaskan (Jawa Pos, 2014).

Keburukan pengelolaan hewan di Kebun Binatang Surabaya, digambarkan dengan kalimat Begitu parahnya kondisi KBS, seekor raja hutan pun yang begitu ditakuti di habitatnya mati dalam kondisi mengenaskan. Dalam dongeng hewan, Singa memang digambarkan sebagai sosok hewan yang kuat, tidak terkalahkan dan berwibawa. Kekuatan dan dan kekuasaan Singa sebagai penguasa hutan, tidaklah mampu ada yang menandingi. Dengan kejadian matinya seekor singa, berarti kondisi lingkungan hidup dimana singa itu berada sangatlah tidak baik sehingga Lead tersebut juga memberi penekanan dalam menyoroti Singa sebagai korban buruknya lingkungan hidup tempat tinggalnya.

Setelah menampilkan keadaan Kebun Binatang Surabaya yang memprihatinkan, Jawa Pos memilih menampilkan kejanggalan yang terjadi pada kematian Michael. Harian Jawa Pos turut memberikan pernyataan akan adanya kejanggalan kematian yang dialami oleh Michael. Kejanggalan-kejanggalan tersebut terungkap melalui beberapa pernyataan yang dituliskan, diantaranya: (1) Anehnya kematian raja hutan tersebut tidak lazim (Jawa Pos, 2014). Ada kemungkinan hewan tersebut dibunuh. Sebab ketika tewas, singa itu terlilit kawat baja yang digunakan untuk membuka pintu. Berdasarkan data yang dihimpun sling tersebut terbuat dari baja sehingga sifatnya tidak elastis (Jawa Pos, 2014). (2) Kejanggalan yang lain tentang waktu kematian Michael adalah waktu kematiannya. Diduga, hewan tersebut dibunuh saat malam (Jawa Pos, 2014). Untuk mendukung penyataan akan kejanggalan kematian Michael tersebut, Harian Jawa Pos menampilkan narasumber dari pihak Perusahaan Daerah Taman Satwa (PDTS) Kebun Binatang Surabaya yaitu Direktur Operasional Daerah Taman Satwa Kebun Binatang Surabaya, drh. Liang Kaspe sebagai narasumber pertama yang ditampilkan dalam wacana tersebut. Kan, tidak mungkin hewan tiba - tiba bunuh diri dengan cara melilitkan kepalanya (Jawa Pos, 2014).

"Sehari sebelum tewas, kata Liang, hewan tersebut masih lincah. Nafsu makannya pun masih normal. Bahkan, sejak dua bulan lalu menghuni KBS, singa itu tak pernah sakit dan ditemukan tanda-tanda penyakit di tubuhnya. Singa itu sangat prima. Tidak

Tabel 5 Treatment Recommendation

\begin{tabular}{c|c}
\hline Jawa Pos & Koran Sindo \\
\hline Polisi dilibatkan dalam penyelidikan kasus & Polisi dilibatkan untuk mengusut kasus \\
\hline
\end{tabular}


mungkin tiba-tiba singa bermain sling tersebut, talinya terkunci rapat (Jawa Pos, 2014)".

"Kejanggalan yang lain tentang kematian Michael adalah waktu kematiannya. Diduga, hewan tersebut dibunuh saatmalam. Sebab, ketika pagi ia sudah ditemukan tidak bernyawa. Liang mengatakan pada saat malam tidak ada pawang atau keeper di kandang. Yang tersisa hanya petugas sekuriti (Jawa Pos, 2014)".

Komentar dari narasumber mengenai kejanggalan atas kematian Michael juga turut dipertegas pihak Harian Jawa Pos dengan mengarahkannya berita pada unsur sengaja dibunuh. Seperti komentar yang dikeluarkan oleh Hendro Gunawan, Sekretaris Kota Surabaya Hendro Gunawan: "Sebab bila dilihat cara kematiannya, mengarah ke sana (kesengajaan dibunuh) (Jawa Pos, 2014)".

Jawa Pos lebih menampilkan beberapa kutipan narasumber dari pihak internal Perusahaan Daerah Taman Satwa (PDTS) Kebun Binatang Surabaya terlebih dahulu daripada pihak eksternal. Namun dari pengamatan peneliti, ditampilkannya Direktur Operasional Perusahaan Daerah Taman Satwa (PDTS) Kebun Binatang Surabaya sebagai narasumber pertama dengan menceritakan kondisi Michael yang sebelumnya sehat, kondisi kandang yang telah sesuai standard, waktu kematian dan lain sebagainya, malah menjadi penegas akan adanya unsur orang dalam dan kesengajaan dalam kematian Michael.

Penulisan berita yang ditampilkan Koran Sindo dilatarbelakangi adanya ketidakmampuan pengelola dalam memelihara satwa di Kebun Binatang Surabaya. Hal tersebut dapat dilihat dari paragraf awal yang dibangun oleh Koran Sindo:

"Pergantian pengelola Kebun Binatang Surabaya (KBS) ternyata tak juga membawa nasib baik bagi para satwa penghuninya. Kematian yang disebabkan kecerobohan atau kelalaian pengelola tetap menghantui ratusan satwa tak berdosa tersebut. Dalam dua hari berturut - turut, dua satwa koleksi KBS mati (Sindo, 2014)".

Kalimat di atas menggambarkan kejadian yang menyebabkan kematian Michael pada
7 Januari 2014, yaitu karena kelalaian dan kecerobohan yang disebabkan pihak pengelola dan buruknya manajemen di Kebun Binatang Surabaya dilengkapi dengan detail mengenai beberapa runtutan peristiwa kematian satwa sebelumnya:

"Setelah Genua Afrika yang tewas akibat kembung pada Senin (6/1), kemarin giliran Singa Afrika. Ironisnya, singa berusia 1,5 tahun itu tewas terlilit tali sling (kawat) pintu kandangnya sendiri. Singa bernama Michael itu ditemukan petugas sekitar 07.00 WIB kemarin dengan posisi kepala tergantung kawat (Sindo, 2014)".

Pada kutipan paragraf di atas tampak bahwa Koran Sindo mengungkap detail kematian satwa yang terjadi secara berurutan di awal tahun 2014, mulai dari Genua Afrika hingga Singa Afrika. Bisa dikatakan detail ini semakin memperkuat pernyataan Koran Sindo bahwa Perusahaan Daerah Taman Satwa (PDTS) Kebun Binatang Surabaya sebagai pengelola baru dinilai tidak dapat bertanggungjawab terhadap satwanya.

Dari sisi Perusahaan Daerah Taman Satwa (PDTS) Kebun Binatang Surabaya, beberapa detail tersebut membuat stigma bagi Perusahaan Daerah Taman Satwa (PDTS) Kebun Binatang Surabaya sebagai pengelola KBS yang buruk. Padahal dalam beberapa kematian satwa yang disebutkan, ada yang disebabkan karena sakit, bukan hanya karena kejadian yang tidak wajar. Maksud tersebut diuraikan secara eksplisit dari paragraf-paragrafnya, terutama pada paragraf berikut:

"Selain dugaan kelalaian bahkan bisa jadi kesengajaan, kematian satwa di KBS disebabkan perawatan kandang yang buruk. Hal ini diperparah dengan tidak berimbangnya jumlah satwa dengan kandang yang tersedia (Sindo, 2014)".

Pengambilan narasumber Koran Sindo lebih cenderung menempatkan pihak luar Perusahaan Daerah Taman Satwa (PDTS) Kebun Binatang Surabaya lebih dahulu dibanding dengan penempatan pihak Perusahaan Daerah Taman Satwa (PDTS) Kebun Binatang Surabaya sendiri. Dan yang lebih mengejutkan Koran Sindo mengambil narasumber Ketua Forum Konservasi Satwa Liar Indonesia (Foksi) Jatim, 
Michael Sumampau. Apabila ditelusuri lebih, Michael Sumampau merupakan putra dari Tony Sumampau, ketua pengurus Kebun Binatang Surabaya yang sedang berkonflik dengan Perusahaan Daerah Taman Satwa (PDTS) Kebun Binatang Surabaya.

Baik untuk Harian Jawa Pos dan Koran Sindo memberikan penggambaran mengenai kasus kematian Michael dengan penggambaran bahwa Michael, singa afrika yang meninggal adalah korban dari tindakan kasus tersebut. Polisi merupakan lembaga pemerintahan Republik Indonesia yang berfungsi di bidang pemeliharaan keamanan dan ketertiban masyarakat, penegakan hukum, perlindungan, pengayoman, dan pelayanan kepada masyarakat dalam keterkaitan dengan kematian Michael, dilihat sebagai sebuah peristiwa yang akan mampu menimbulkan konflik atau ketidaktertiban terhadap aturan dalam masyarakat. Peristiwa yang ada unsur keterkaitan dengan pelanggaran hukum, misalnya pembunuhan terhadap satwa, tindakan yang disengaja untuk membunuh.

Didesak, merupakan gabungan dari awalan di dan kata dasar desak

di imbuhan yang ditambahkan pada bagian awal sebuah kata dasar atau bentuk dasar, awalan terkait dikenai laku, tindak, dikenai dengan (Kamus besar Bahasa Indonesia, 2008).

desak, mempunyai makna memaksa, penting untuk segera dilakukan, meminta dengan sangat (Kamus besar Bahasa Indonesia, 2008).

Dari penjabaran kata tersebut dapat dipersepsi judul Polisi Didesak Selidiki Satwa Tewas, bahwa kejadian tewasnya satwa di Kebun Binatang Surabaya menuntut pihak Polisi sebagai lembaga negara yang berfungsi menjaga keamanan untuk menyelidiki, memeriksa terhadap faktor - faktor terkait peristiwa kematian satwa di Kebun Binatang Surabaya. Secara tidak langsung Perusahaan Daerah Taman Satwa (PDTS) Kebun Binatang Surabaya, diposisikan sebagai tempat terjadinya pelanggaran, kejahatan, dan kriminalitas terhadap hewan.

Polisi,sebagaipihakyangbertanggungjawab terhadap keamanan dan tindakan kriminalitas juga dimunculkan oleh Harian Jawa Pos. Pelaporan kasus kematian Michael dilakukan ke pihak polisi untuk melihat adanya unsur bahwa raja hutan memang mati dengan disangkutkan di tali baja oleh pihak tertentu. Berbeda dengan Koran Sindo, Jawa Pos menyoroti terlambatnya pelaporan yang dilakukan Perusahaan Daerah Taman Satwa (PDTS) Kebun Binatang Surabaya sehingga menyebabkan polisi yang datang ke tempat kejadian perkara (TKP) tidak dapat secara maksimal melakukan penyelidikan karena TKP telah rusak.

Pada sub judul kedua Polisi Harus Ungkap Keterlibatan Orang Dalam. Teks tersebut menunjukkan adanya pihak Perusahaan Daerah Taman Satwa (PDTS) Kebun Binatang Surabaya yang turut serta sebagai pelaku, atau dikatakan mempunyai rencana dan eksekusi atas kematian Michael.

Pada Citra Perusahaan Daerah Taman Satwa Kebun Binatang Surabaya dalam Bingkai Berita Jawa Pos dan Koran Sindo, M. Vos mengemukakan bahwa citra perusahaan (corporate images) dapat diartikan sebagai:

Gambaran organisasi di mata publik, akibat pengalaman yang membentuk pikiran seseorang, yang mampu menggambarkan pikiran yang samar - samar menjadi jelas, pandangan seseorang yang terbatas menjadi menyeluruh, dapat menjadi lebih baik atau lebih buruk dari identitas perusahaan sebagai bentuk evaluasi, dan pada akhirnya citra akan mempengaruhi perilaku individu terhadap organisasi. (Vos, 2000: 28)

Citra merupakan bagian penting dalam Public Relations, apa yang dipersepsi oleh publik tentang perusahaan akan mampu mempengaruhi sikap publik terhadap perusahaan. Untuk itulah penting adanya bagi seorang Public Relations Officer untuk terus berusaha menjaga citra perusahaan agar tetap positif di mata publik.

Citra Koran Sindo terhadap Perusahaan Daerah Taman Satwa (PDTS) Kebun Binatang Surabaya ditampilkan pada adanya kecerobohan dan kelalaian Perusahaan Daerah Taman Satwa (PDTS) Kebun Binatang Surabaya terkait pengelolaan satwa, hingga terjadi kematian yang tidak wajar dan akibatnya polisi dirasa perlu untuk menyelidiki kasus kematian Michael yang mati tergantung.

Penyusunan berita dilakukan Koran Sindo dengan memberikan unsur-unsur yang mampu mendukung wacana yang ingin dibangun mengenai stigma negatif Perusahaan Daerah 
Taman Satwa(PDTS) Kebun Binatang Surabaya. Beberapa inti dari tiap paragraf yang ingin dibangun Koran Sindo mengacu pada sub topik: kematian satwa yang disebabkan kecerobohan pengelola, terdapat unsur kesengajaan dalam kematian Michael, pemerintah Kota Surabaya baru mengambil tindakan setelah ada kematian satwa berturut-turut, dan polisi turut dilibatkan dalam kasus Michael. Sehingga dari sub pokok paragraf-paragraf tersebut makna yang terbangun menjadi kecerobohan dinilai menjadi unsur kesengajaan yang menyebabkan kematian satwa sehingga keterlibatan polisi diperlukan untuk menyelidiki lebih jauh kasus yang terjadi.

Penggunaan kata buruknya manajemen, kelalaian, kecerobohan, kesengajaan dan juga kalimat pada judul gambar menunggu kematian di KBS. Menjadi penguat akan stigma buruk yang diberikan Koran Sindo kepada Perusahaan Daerah Taman Satwa (PDTS) Kebun Binatang Surabaya. Pengambilan narasumber Koran Sindo lebih cenderung menenpatkan pihak luar Perusahaan Daerah Taman Satwa (PDTS) Kebun Binatang Surabaya lebih dahulu dibanding dengan penempatan pihak Perusahaan Daerah Taman Satwa (PDTS) Kebun Binatang Surabaya sendiri. Koran Sindo mengambil narasumber Ketua Forum Konservasi Satwa Liar Indonesia (Foksi) Jatim, Michael Sumampau. Apabila ditelusuri, Michael Sumampau merupakan putra dari Tony Sumampau, ketua pengurus Kebun Binatang Surabaya yang sedang berkonflik dengan Perusahaan Daerah Taman Satwa (PDTS) Kebun Binatang Surabaya.

Jawa Pos dalam penyusunan pemberitaan kematian Michael lebih menyoroti adanya Kondisi Kebun Binatang Surabaya sudah tidak layak bagi satwanya dan kesengajaan, menjadi penyebab kematian Singa KBS mati tergantung. Paragraf-paragraf yang disusunnya mengarak pada sub topik: Kondisi KBS yang memprihatinkan dengan terus terjadinya kematian satwa, Terdapat Kematian satwa KBS yang disertai kejanggalan penyebab kematiannya, yaitu digantung, Adanya unsur keterlibatan pihak dalam Perusahaan Daerah Taman Satwa (PDTS) Kebun Binatang Surabaya dalam kasus kematian Michael, Singa Afrika, Terlambatnya waktu pelaporan kejadian Michael dan olah TKP yang tidak maksimal karena TKP sudah tidak murni. Sehingga dalam makna keseluruhan bagian berita yang ditampilkan mampu memberikan makna Kematian satwa KBS menimbulkan kejanggalan karena mati digantung dan tempat kejadian perkara yang telah dibersihkan sebelum penyelidikan. Kejanggalan, keterlibatan orang dalam, memprihatinkan, TKP rusak, telat melapor, menjadi penguat adanya citra yang diberikan Harian Jawa Pos kepada Perusahaan Daerah Taman Satwa (PDTS) Kebun Binatang Surabaya.

Melalui pemberitaan dalam kematian satwa itulah perception trully does become reality (Regester, Michael \& Judy Larkin. 2008: 173). Realitas yang di hadirkan oleh Harian Jawa Pos dan Koran Sindo mampu mengarahkan publik pada persepsi bahwa realitas kelalaian Perusahaan Daerah Taman Satwa (PDTS) Kebun Binatang benar adanya. Jean Baudrillard (1981) mengungkapkan antara realitas yang ditampilkan media akan mampu mengarahkan pada relasi citra yang terbentuk dalam benak publik, diantaranya: citra dikatakan merupakan refleksi dari realitas atau citra menopengi dan memutarbalikkan realitas (Piliang, 2003: 46).

\section{SIMPULAN}

Citra Perusahaan Daerah Taman Satwa (PDTS) Kebun Binatang Surabaya dalam Harian Jawa Pos memperlihatkan adanya kondisi Kebun Binatang Surabaya sudah tidak layak bagi satwanya dan kesengajaan keterlibatan orang dalam menjadi penyebab kematian Singa KBS mati tergantung. Citra Perusahaan Daerah Taman Satwa Kebun Binatang Surabaya oleh Koran Sindo ditampilkan sebagai pihak yang harus bertanggungjawab atas kelalaian dan kecerobohannya dalam memelihara satwa, sehingga mengakibatkan terjadi kematian satwa yang tidak wajar. Hal tersebut terlihat dari analisis makrostruktur teks yang memaparkan bahwa kepolisian dilibatkan untuk menyelidiki singa yang mati tergantung akibat kelalaian Perusahaan Daerah Taman Satwa (PDTS) Kebun Binatang Surabaya dalam pengelolaan satwa.

Pemberitaan yang dimunculkan oleh media massa patut menjadi perhatian oleh praktisi Public Relations. Berita yang dikonstruksi negatif secara terus menerus dapat memberikan pengaruh negatif pula di dalam benak pembaca. Beberapa pernyataan negatif yang muncul dalam teks pemberitaan dapat dijadikan sebagai dasar perencanaan bagi humas Perusahaan 
Daerah Taman Satwa (PDTS) Kebun Binatang Surabaya dalam penanganan krisis dan perbaikan citra setelah krisis.

\section{DAFTAR PUSTAKA}

Coombs, W. T. \& Sherry J. H. (2010). The handbook of crisis communication. United Kingdom: Blackwell Publishing Ltd.

Eriyanto. (2005). Analisi framing. Yogyakarta: LKIS Yogyakarta.

Jawa Pos. (8 Januari 2014). Raja hutan mati tergantung tali baja.

Kriyantono., R. P. (2012). Public relations \& crisis management: pendekatan critical public relations, etnografi kritis \& kualitatif.
Jakarta: Kencana Prenada Group.

Piliang, Y. A. (2003). Hipersemiotika: tafsir cultural studies atas matinya makna. Yogyakarta: Jalasutra.

Santoso, A. (2003). Bahasa politik pasca orde baru. Jakarta: Wedyatama Widya Sastra

Sindo. (8 Januari 2014). Polisi didesak selidiki satwa tewas.

Sobur, A. (2002). Analisis teks media,suatu pengantar untuk analisis wacana, analisis semiotika, dan analisis framing. Bandung: Remaja Rosdakarya.

Vos, M. F. (2000). The corporate image concept: a strategic approach. Nederlands: ACC Ede. 